\title{
From physical to online spaces in the age of the \#FeesMustFall protests: A Critical Interpretative Synthesis of writing centres in emergency situations
}

\author{
Robert Doya Nanima \\ Postdoctoral Research Fellow, Dullah Omar Institute, University of the Western Cape \\ E-mail: rnanima@gmail.com
}

\begin{abstract}
Writing centres play a vital role in guiding students in their academic writing. Central to this role is their physical location at tertiary institutions, where students usually walk in and schedule appointments with writing tutors. The recent \#FeesMustFall protests saw the temporary closure of universities across South Africa. As a result, the functionality of the writing centres as physical locations was disrupted to the detriment of student development. This article evaluates the application of the principles that underscore the operation of physical writing centres as online spaces. First, it evaluates the writing centre as a physical space, and the resulting shift to an online space as a result of the \#FeesMustFall protests. Secondly, with the methodological aids of Critical Interpretative Synthesis and my personal reflections as a tutor, I analyse the possible application of the principles that guide physical writing centres to the online environment.
\end{abstract}

Keywords: \#FeesMustFall, online spaces, physical spaces, tutor-student relationships, writing centres

\section{Introduction}

Writing centres at tertiary institutions offer a space for students to improve their academic writing. A wave of student protests, dubbed "\#FeesMustFall", took tertiary institutions by storm between 2015 and 2017, affecting the operations of various departments, institutions, and faculties. As physical spaces, most writing centres were not open to students during this turbulent time. Some insightful research has been done since then (Badat 2016, Boughey and McKenna 2016) but with little or no emphasis on these writing centres' modes of operation during the protests. While scholars state that the student protests had economic, political, ideological, and organic undertones (Badat 2016), the operation of writing centres during this period has not been accorded adequate attention. Attention ought to have been accorded to writing centres because of the role they play in improving the academic writing of students at tertiary institutions across disciplines. Writing centres offer students the opportunity to develop their academic voice via the interrogation of knowledge through writing; the closure of these 
centres, however temporary, deprives these students of these developmental opportunities and their ability to use this voice. While there are various issues that speak to the ideology and goals of a writing centre, this contribution, by design and logistics, focuses on the continued operation of writing centres where students are unable to have face-to-face sessions with the tutors. In the wake of the student protests, I question how writing centres can connect with students when the latter are unable to come to the physical space for consultations.

This study relates literacies to the \#FeesMustFall student protests and validates the interrogation of the operation of writing centre spaces during these protests. However, I recognise that there may be other reasons that may inform students' failure to get to campus. While there is extant literature that models writing centres as transitional spaces, this articulation does not connect the transition to online spaces (Nichols 2017). If this problem is not dealt with, the probable non-operation of writing centres, when students cannot get to campus to attend consultations due to protests or other reasons, will continue unabated. This is based on my observation that the University of the Western Cape (UWC) Writing Centre did not function during these protests, and never developed a contingency plan to deal with recurring emergencies and temporary disturbances in operation. In order to keep the teaching and learning going as far as possible during these protests, essay assignments in the form of continuous assessments were given by lecturers as the contingent mode for semester exams. Thus, student consultations with tutors at an open and operational UWC Writing Centre were necessary more than ever, but could not take place due to these protests.

The aim of this study is to evaluate the principles that apply to the running of writing centre spaces as physical spaces and to test these principles against the practical application of online centres when adopted as short-term solutions to emergency situations. An evaluation of the operation of the writing centre during the \#FeesMustFall protests is undertaken. Scholarly writing and personal experience are used as evidence to support my argument and sub-claims. The study seeks to establish whether the application of these principles to an online platform offers the same advantages to students as do face-to-face consultations. Central to this aim is how the physical and online space may deal with aspects of power, authority, and identity.

\section{Literature review}

\subsection{Operation of writing centres as physical spaces}

There are various conceptions of a writing centre as a physical or online space in terms of what the centre does, the strategies that inform its existence, and the challenges that arise. These conceptions are instructive in determining whether a writing centre should be both a physical and online space, and how it grapples with the challenges of balancing power, authority, and identity in the peer-student relation within its space. By design, this study looks at the various perceptions that inform the existence of a writing centre in addition to conducting a literature review of the definitions of a writing centre as either a physical or online space.

A writing centre is a space that aids the improvement of student writing. According to Clarence (2011), a writing centre is a space that focuses on the holistic development of a student's academic writing. She argues that writing centres play a key role in cooperating with academic lecturers to advance nuanced writing-intensive teaching methods and materials. The holistic development of a student is central to the guidance offered by tutors to students across all disciplines and faculties. 
Clarence (2011) uses her own experiences at the UWC Writing Centre to show the extent of collaboration with students and with lecturers. Denny (2005) posits that the power of the tutor during the consultation should be used in a manner that recognises the identity of the student. It should be noted, however, that while this observation is made in the context of the physical space, it is not a qualification that limits this approach to physical spaces only.

The writing centre is also a walk-in space, usually found at tertiary institutions, to which students are able to bring their tasks and assignments for consultation. Clarence (2011) contextualises this walk-in space as a physical space with an administrative structure that supports the receipt and assignment of drafts to tutors, and the preparation and conduct of peerled writing tutorials. This emphasises the extent to which writing centres are recognised as physical spaces. The success of a writing centre in helping students lies in how it engages pedagogical inclusiveness across all disciplines in light of the nature of students who visit it. Nichols (2017) argues for a reconceptualisation of the role of the writing centre as a space that aids the education system through pedagogic inclusiveness that articulates without normalising the differences, exclusionary practices, and transitional spaces. In this vein, where the writing centre articulates differences, it exhibits subjectivity in its responses to and engagements with students. This points to a transition in the mode of operating within a physical space, and not necessarily a transition from the physical space, through the guidance that a tutor offers to the student's thought- and writing processes by questioning and clarifying so that the student can adequately convey their meaning more effectively and confidently. Secondly, it speaks to the need to retain the identity and voice of the student in consultations.

At the core of the consultations that take place in the writing centre space is the art of questioning and clarification as effective tools that aid traditional consultation. This position is, to a great extent, fortified by Munje, Nanima and Clarence (2018) who interrogate the role of questioning in writing centre tutorials. They question how tutors can create a space for student writers to "take ownership of their writing, reflect on the process of creating a piece of writing, and learn about themselves as writers in ways that enable further growth and learning" (Munje et al. 2018: 338). Furthermore, Munje et al. (2018: 358) argue that "peer tutors position themselves alongside students, physically and figuratively, sitting beside them in the writing centre, and working with them to question, challenge, support and advise". This lends credence to the view that the writing centre is a physical rather than an online space (Deane and Ganobcsik-Williams 2012). Thus it is critical that the manner of questioning balances the authority that the questions reflect in light of the student's identity.

Nichols (2017) offers hopeful directions for South Africa's writing centres as transitional spaces to develop constructive thinking rather than using tutors to offer quick solutions to students. She argues for the need to reconceptualise the role of the writing centre space from the introspection of the early 1990s to the student protests in 2015. She poses three subarguments: (i) an education system may fail a society due to the lack of inclusiveness in the mode of teaching, (ii) the need to use the writing centre as a space to articulate differences, and (iii) that this articulation exhibits subjectivity as a tool that offers prudent responses in a time of crisis. Her evidence for these claims rests on her evaluations of the works of Delpit (1995), Grimm (1999), and Baldwin (in Peck 2017), respectively.

Furthermore, Nichols' (2017) contribution brings to the fore the position of the tutor in this articulation. The tutor's position of authority is highlighted as s/he helps the student to navigate 
the articulation of differences or ideas. In this regard, the tutor's main challenge is to remain a tutor without imposing his/her views yet still maintaining the position of authority (Carino 2003). This is an indication that a student's loss of confidence in the tutor's authority leads to a decrease of interest of the former in the tutoring sessions. There is a greater risk of this occurring in online consultations where many of the "human" elements of consulting are absent.

Nichols asserts that a peer tutor offers guidance to 'the student's thoughts and writing processes by questioning and clarifying, so that students learn to convey their meaning more effectively, and feel confident to be able to enter the academic debate" (Nichols 2017: 5). One is left to choose an approach that either monitors the "wrongness" of a student or that embraces connectedness and listening. A similar position is evident in Archer and Richards (2011) who argue that writing centres use dialogue and the sharing of ideas to aid students' development of their academic writing. Although Archer and Richards (2011) and Nichols (2017) push for the writing centre to move from conventional student assistance to enabling these students to articulate their ideas, this is intrinsically linked to the need to control power relations and authority in a way that, in part, upholds the identity of the student. This is effected through the way that the tutor balances his/her power and authority while attempting to recognise the identity of the student in his or her work. Nichols' articulation of difference requires a discipline from tutors that focuses on listening in order to aid position-taking and the substantiation thereof. While her introduction leans towards the writing centre as a physical space, this conversation can also be extended to question the relevance of these principles in the online space.

Some of the key aspects that are present in physical writing-centre spaces are issues of power relations (Shabanza 2017), authority, and identity (Mitoumba-Tindy 2017), all of which need to be tested against the literature on online writing centres. The challenge and opportunity present in the physical space involve how the tutors are able to balance their position of power and authority with due regard to the identity for the student in the writing centre. In a physical space with face-to-face consultations, the tutor's presentation in terms of facial expressions and proximity to the student as persons of authority and power are more easily managed in the conversation. The position is more difficult when the comments are typed up in an email or on social media such as WhatsApp, Facebook or Skype.

\subsection{The operation of writing centres as online spaces, and the challenges that arise}

The contextualisation of online writing addresses the three issues identified in the conversation on writing centres as physical spaces. As noted earlier, these issues include power relations (Shabanza 2017), authority, and identity (Mitoumba-Tindy 2017).

From a global perspective, writing centres have been predominantly physical locations. As a move that started in the United States, there has been a gradual shift from the physical to an online space to improve tutors' fluidity regarding the improvement of students' work (Burch, Good and Heinrich 2016). Faroa (2017) argues that the mode that tutors utilise to engage and interact with students is close to physical interaction. To put this argument across, the author explores the implications of running an online writing centre, the administrative issues that arise and how they are dealt with. He recommends that the online platform should be envisaged as a decentralisation of the writing centre from the physical to the online space that enhances rather than threatens its autonomy in the physical space. The lack of insight into how online writing 
centres balance tutor-student relationships in terms of power, authority, and identity is established as a gap that this article seeks to address.

Tan (2011) instigates an introspection of the relationship between the physical and the online spaces. It is argued that the online writing centre assumes the credibility that is assigned to the physical space. The main argument for the use of an online writing centre on its own or as an extension of the physical space is the increased access it offers to a person who may not be able to come in person to the physical space (Zakharov and Maybee 2019). This is instructive in forging solutions for instances where a student cannot get to campus yet $\mathrm{s} /$ he needs to consult with one or more tutors at the writing centre. This speaks not only to the closure of writing centres during emergencies, but also to when the student has valid reasons which prevent him or her from getting to campus.

Breuch and Racine's (2000) study takes a rather different approach as it identifies the problem that affects the relationships within the two spaces. It argues that tutors trained in physical writing centres are inadequately prepared for the challenges they may encounter in online writing centres. To substantiate their argument, the authors offer a snapshot of the online environments of administrators, developers, and tutors to illustrate the issues that are unique to an online tutoring system, such as the text-only environments and the use of online responses. They offer suggestions that are crucial for the success of the tutor's online platform. This article is selected over others (e.g. Arzt, Barnett and Scoppetta 2009; Boehm 2009; Van Waes, Van Weijen and Leijten 2014) because it contains extracts of feedback from an online writing centre which are strategic in terms of the balance of power, authority, and identity (Breuch and Racine 2000). I am aware that online technology has evolved considerably worldwide since the publication of Breuch and Racine's article (see, for instance, Weirick, Davis and Lawson 2017). However, what is important in their article is how the tutor is able to balance power, authority, and the identity of the student in both environments. With regard to power, the interactions in the physical space may be interwoven in the nature of extensive feedback that the tutor gives the student. In addition, the balancing of authority lies in the clear, concise, and informative style that tutors use to write to the students while considering the needs and anticipations of the students' reactions to the text. As such, the reactions of the students to the written comments inform their identity as writers in the piece of writing.

Central to this study are the following two questions: (i) How does an online writing centre deal with aspects of power, authority, and identity (Mitoumba-Tindy 2017, Munje et al. 2018, Shabanza 2017, Thompson 2009), and (ii) How can the online space operate effectively under circumstances that do not exhibit the characteristics of a physical consultation? Breuch and Racine (2000) identify a few challenges that online centres face, the first being time management in an online tutoring session. This challenge may be countered by the possibility of online tutoring on synchronous platforms like Skype, or asynchronously through the use of a defined period to prepare and email feedback. The lack of physical space and a welcoming atmosphere for the student is the second challenge for online centres, and thirdly, the fundamental changes in the interaction (see also Monroe 1998). It is argued that a reconciliation of these challenges as a yardstick for the success of an online writing centre is key to establishing its possible effectiveness. This effectiveness has to be evaluated when physical spaces cannot be accessed. Breuch and Racine (2000) state that the online writing centre needs to maintain the same pedagogical goal of student centeredness through student-focused pedagogies. They advocate for specialised training for online tutors so as to offer an online environment that makes the student 
feel welcome and confident in the online space. Although not explicitly, they offer insights on how to use text-only environments, improve online responses, and rethink the roles of online tutors. In the interim, an online writing centre should be able to offer this one-to-one, individualised, non-directive, and non-threatening service (Hoon 2009).

With regard to power, the tutors have an obligation to provide thorough written feedback to students on their writing. Written comments empower the student to embrace and engage them in order to improve his or her work. Before having a look at some comments from an online conversation, there is a need to understand the \#FeesMustFall protests and their effects, especially on the operations of writing centres.

\section{3 \#FeesMustFall and its effect on writing centre space}

This section engages the available literature on the operation of writing centres as physical and online spaces, and deals with aspects of power, authority, and identity. These three aspects are then visited in relation to the \#FeesMustFall protests. The gaps that are identified are then used to inform the recommendations that will be made.

The \#RhodesMustFall movement was the pre-cursor to the \#FeesMustFall movement which started with the first act of defiance from Chumani Maxwele on 9 March 2015. Maxwele threw human waste onto the statue of Cecil John Rhodes at the University of Cape Town (UCT) as an act of protest against the colonisation of higher education. Subsequently, overwhelming pressure from both students and the public informed the decision by the UCT Council to remove the statue. The \#RhodesMustFall campaign ultimately led to protests by students across South African universities to demand free higher education (Ludski 2015, in Pillay 2016).

The \#FeesMustFall movement started in Johannesburg after the University of the Witwatersrand (Wits) declared an unaffordable rise in fees for 2016. Wits claimed that the subsidy of 5\% from the South African Government would not be sufficient to accommodate the net increase in costs for this university - for academics' salaries, research equipment, library books, and journal subscriptions. Rhodes University in Makhanda (formerly Grahamstown) then announced a minimum initial payment of $50 \%$ of the fees for 2016 , meaning that the average student living in a student residence needed to pay upfront an amount of R45, 000. The \#FeesMustFall movement became a rallying cry for economically disadvantaged students to protest against financial exclusion and debt traps. It should be noted that the organisers of the various protests employed digital activism through the use of social media platforms such as Facebook, Twitter, and other instant messaging services, to communicate and organise meetings and protest marches (Nyamnjoh 2016, Pillay 2016).

The \#FeesMustFall movement effectively disrupted university functionality across South Africa, and spaces such as writing centres were closed as a result. The UWC Writing Centre was closed during the protests from October 2015 to January 2016, and again from August to October 2016. Another key reason for the \#FeesMustFall protests at many South African universities was inequitable racial representation among the teaching staff (Langa 2017) in addition to the need for free higher education since this was inadequately funded by the State (Badat 2016). The use of violence by protestors, and the heightened presence of security personnel, effectively led to the shutdown of many campuses across the country (Langa 2017). 
It has been argued with regard to academic literacies that the protests project a correlation between literacy and higher education, depending on the conceptualisation one has of literacy and how one understands the rigours of higher education (Boughey and McKenna 2016). This assertion is based on the argument of engaging the decolonised learner in the wake of academic protests. It is argued that the conversation should stretch beyond protests to instances that lead a student to fail to get to campus. A broader perspective involves the use of a wider correlation of reasons that cause the student's failure to attend the face-to-face session, and the continued relevance of the writing centre. During the protests, the UWC Writing Centre could not operate in its physical space and had to move its services online without any preparation for this consultation mode. Like many other universities on the African continent, UWC has access to severely limited and dwindling resources. This is why an online writing centre has not been developed and no training or infrastructure exist for it. Additionally, many students have limited access to WiFi and online facilities when off campus. Many students are also generally less computer literate than their Northern peers due to growing up in underprivileged homes and having attended inadequately resourced schools. All of this makes transitioning to an online writing centre very challenging.

\section{Methodology}

This contribution uses Critical Interpretative Synthesis (CIS), a methodology that is used to describe, interpret, and challenge findings for meaning, context, and influence in order to answer theoretical questions rather than produce definitive claims of effect (Dixon-Woods et al. 2017, Tetui et al. 2018). CIS borrows principles from systematic review and uses them with qualification through the critical examination of decisions made by authors while conducting and publishing their research and practice (McFerran et al. 2017). As such, the meaning (context) that is attached to a physical writing centre can be questioned in terms of its relevance in times of disruption when accessibility is limited. As a consequence, this engagement should speak to the challenges that arise on the online platforms that present solutions in the physical spaces.

The CIS methodology has its roots in medical research based on some of the principles from systematic reviews (Ako-Arrey et al. 2015, Tetui et al. 2018). According to Dixon-Woods et al. (2017), CIS can be used in research settings other than medical literature by applying the principles of this methodology to other settings. As such, in the same way that therapists use findings based on theoretically-informed literature reviews and studies to inform their practice, one can evaluate the research findings that illuminate writing centres as physical and specifically online spaces. I view a writing centre as a space that offers guidance to students who need to improve their writing, usually in a physical space. As previously mentioned, the functionality of many South African university writing centres was greatly affected by the \#FeesMustFall protests that resulted in the closure of several tertiary institutions for an extended period. The CIS analysis will aid the engagement with the principles that guide the operation of writing centres and will show how the online space may be harnessed.

The use of the CIS process involves six steps which include: the formulation of the review question, a search for the available literature, sampling, the determination of quality, the conduct of the CIS, and the conduct of the analysis (Dixon-Woods et al. 2017). It is worth noting that while these steps build on those employed in the use of systematic reviews, they are flexible to use since they do not offer a definite number of articles or materials for review. This is based on the proposition that the CIS may require an objective use of the steps listed above 
during the research process in order to obtain results that offer a practical application of the findings (Pozzebon 2004).

In this paper, CIS is used for three reasons. First, it is a systematic method that enables the analysis of various multifaceted literature (Ako-Arrey et al. 2015). The complexities of this literature lie in the various themes that underlie the research on writing centres. Secondly, CIS permits the development of new concepts and theories through interpretation (Tetui et al. 2018). These concepts may be based on the available literature or the themes that inform the operation of physical writing centres on an online platform. Finally, CIS enables the researcher to use a more flexible approach in assessing the extent to which new concepts may be interpreted to work in different environments (Ako-Arrey et al. 2015, Dixon-Woods et al. 2017). This principle enables the researcher to use, qualify, and interpret the application of principles in a physical writing centre environment in relation to an online platform. On the basis of these three reasons, I utilise the six steps of the CIS process in order to identify concepts from the operation of the writing centre as a physical space, and apply these concepts to an online platform during times of disruption.

Although I make use of a literature review to drive the inquiry, it goes beyond establishing what has been written on the topic under evaluation. This study also engages thematic aspects of the process of the writing centre environment from the UWC Writing Centre. The point of departure is the emphasis on the need to improve the effectiveness of writing centres at any time when the student is unable to get to campus and have the face-to-face session with a tutor. The literal and theoretical underpinnings are tested to offer logical solutions. This methodology enhances the arguments and sub-arguments that guide the operation of a writing centre as a physical or an online space, and how it balances power, authority, and identity in the peer-tutor relationship. This methodological process adds to the evaluation the effectiveness of writing centres as they shift from physical (Clarence 2011, Nichols 2017, Munje et al. 2018) to online spaces (Breuch and Racine 2000, Hoon 2009) in the wake of the \#FeesMustFall protests.

\section{Application and discussion}

This section details the utilisation of the six CIS steps, however, the final step is covered in section 5 below. This research was guided by the question it seeks to answer, namely, whether the principles of the development of student identity and the management of power and authority in physical writing centres can be used in online platforms during periods of disruption at tertiary institutions. This question was used as a compass rather than as an anchor (Eakin and Mykhalovskiy 2003) in that I questioned the effectiveness of a writing centre as an online space during periods when the physical writing centre was inaccessible or when the student, for some or other reason, could not get to campus.

The second step involved searching for literature on the available digital databases ( $\mathrm{Da}$ Costa and Jüni 2014). The danger of this approach was the possible exclusion of deserving materials from the search because they did not conform to the search's strict criteria (Greenhalgh, Robert, Macfarlane, Bate, Kyriakidou and Peacock 2005). I used the following keywords: "tutors and students in writing centres"; "online writing centres"; "physical writing centres"; and "\#FeesMustFall". This generated 119 results which were subjected to an inclusion/exclusion criterion. Further scrutiny required that the papers had to be published in peer-reviewed journals, and the focus had to be on writing centres at tertiary institutions. Furthermore, I sourced and used 
literature that was less than five years-old to ensure that the findings were based on an evaluation of recently created knowledge. Ultimately, this returned 19 usable results.

Thirdly, purposive sampling was used to identify materials that offered thematic aspects of the peer-student relationship in the writing centres and of the student protests in the lens of the writing centres' operation (Bonell et al. 2013). Out of the 19 papers, I identified six thematic areas that spoke to writing centres, their operation as physical and online spaces, and the contextualisation of \#FeesMustFall. This narrowed the number of papers to be examined to six peer-reviewed articles.

Fourthly, the identified articles were subjected to quality assessment. I used a two-pronged approach that scrutinises the papers for either inclusion or exclusion (Dixon-Woods et al. 2017, Tetui et al. 2018). Five factors were used to determine the quality of the papers: (i) clarity in the aims and objectives of the research, (ii) the appropriateness of the research design to the aims and objectives, (iii) the researcher's clear account of the process that led to the findings, (iv) the sufficiency of the data to support the interpretations, and (v) the appropriateness of the methods of analysis.

The next step was to conduct the CIS in three sub-steps of comparison, contrast, and interpretation. This included the identification of key concepts that each study dealt with in comparison with the other studies (Dixon-Woods et al. 2017), and an assessment of the existence of contradictions and possible explanations thereof (Pound et al. 2005). Following this was the interpretation of the concepts and their possible application to an online writing centre (Tetui et al. 2018). The literature on CIS does not state that a chronological analysis has to be followed (Dixon-Woods et al. 2017, Pound et al. 2005, Tetui et al. 2018). I identified the thematic areas, whether they related to physical or online writing centres, and proposed ways of using them to ensure the effectiveness of writing centres during times of disruption.

\section{Analysis and discussion}

The analysis and discussion forms the sixth step of CIS methodology, and performs three functions. First, through an evaluation of the literature identified above, the analysis hinges on how the themes balance power and authority, and develop the identity of students. Secondly, it questions how these themes can be engaged practically to aid the use of online spaces when the physical spaces are not accessible. Thirdly, I draw on my experiences as a tutor at the UWC Writing Centre to engage the foregoing literature. This chronology is followed in the three distinct subsections that follow, that is, training and effective feedback, use of spoken language as written language, and questioning.

It should be recalled that in a consultation, the identity of the student through the projection of his or her voice in the work is foremost (Clarence 2011) and, at the same time, a consultation needs to improve the student's work (Faroa 2017). With regard to authority, the tutor presents a position of confidence from which the student receives guidance in the navigation of his or her ideas (Carino 2003). The identity of the student is then evident in the work $\mathrm{s} /$ he presents through the tutor's balance of power and authority (Denny 2005). It should be kept in mind that the unifying aspect of the identified literature is that the studies took place under stable environments where no protests arose. 


\subsection{Training and effective feedback}

With reference to effective feedback, Weissbach and Pflueger (2018) note that students are usually sent to physical writing centres to improve their work. They point out that more often than not, tutors lack the technical background required for some of the assignments that the students present. This three-year study established that the development of interdisciplinary training led to useful feedback given to students. While the research shows that after this training, the tutors were appreciated by the students for helping them, what was missing was the requisite interplay between the use of power to maintain identity in the form of the students' voice in the work (Clarence 2011, Faroa, 2017). This is because the research did not measure whether the students' writing skills or understanding of engineering principles improved due to tutoring. The aspect of authority (Carino 2003) could only be deduced from the positive feedback that the tutors received after using the skills from the training sessions in their tutorials. However, this is diluted by the finding that the students still preferred to receive feedback from tutors who had technical knowledge of the subject (Weissbach and Pflueger 2018). Furthermore, the research findings were based on individual reports from the students without a corresponding in-depth analysis of the effectiveness of the feedback from the tutors (Weissbach and Pflueger 2018). It is argued that while this study pointed to the need for training, the failure to analyse the feedback leaves little that one can take from the physical writing centre to the online space. This leaves us with the question of how feedback can be harnessed and measured in an online writing centre.

Weirick et al. (2017) attempt to answer this question. They conducted a study on effective feedback through online writing centres, and identified three themes that may be used to measure tutors' skills in online engagement. These include the type of comment, the focus of the comment, and the mode of comment. In respect to the type of comment, the tutor is expected to use global comments in reference to the content, surface comments to deal with clarity and sentence structure, and meta-text comments to deal with the context of the consultation session (Weirick et al. 2017). The authors state that the focus of a comment refers to the correctness of the text, the organisation of the paper, and the writing style. Finally, the mode of comment refers to how the tutor communicates his/her feedback to the student in terms of his/her advice, questions or critique (Weirick et al. 2017). This study leans toward the use of training on how to navigate the use of feedback for the success of online writing centres. In this regard, it is argued that Weirick et al.'s (2017) engagement with the mode of comment is instructive in aiding the use of the online writing centre in balancing power, in terms of the tutor's authority, with the student's identity.

I recall two sessions at UWC's Writing Centre that offer a good contrast of the need to measure effectiveness and feedback though emails. Although both were walk-in sessions, a lot can be garnered from them in terms of the need to balance the power, authority, and identity of the student. With reference to the two tutors who joined the UWC Writing Centre at the same time and were subjected to the same training, their approaches were different. While one tutor placed the student "on the spot", the other tutor was corrective.

Tutor A gave the following feedback to his student:

You have plagiarized this section. You must go back and rework it. You are a Masters' student. 
The student did not respond well to this: he felt humiliated, judged, and as though he did not have a choice about revisions to his own paper.

Tutor B, on the other hand, gave the following feedback to his student who had the same problem as Tutor A's student:

Consider rewording this section.

By giving this feedback, Tutor B left the choice in the writer's hands while asserting his own authority as writing tutor. This student responded well because Tutor B was sensitive to and respectful of the student's identity as the author of the work. The tutor's decision not to place the student "on the spot", but rather bring the mistakes to the attention of the student, mitigated an aggressive reaction from the student which could have affected the final improvement of the work. While the student's identity as the author of the work was maintained, the tutor calmly asserted the need for a revision of the work.

A similar scenario ensued where the assignment was from a science department, and most of the tutors did not have the technical knowledge of the subject. The lecturer of the course provided the rubric and the instructions, and requested that the tutors then guide the students on how to develop consistent and coherent arguments. This approach provided the tutors with insights on what was required by the lecturer, thus enabling them to balance their power and authority in guiding the students to maintain their identity in the assignment.

Without prejudice to the foregoing examples, one may still argue that training is an imperative solution for online tutorials. This is a complex matter that starts with the approach a tutor has towards helping a student who cannot access the physical writing centre, and to other factors that $\mathrm{s} /$ he has no control over. In reference to the attitude of a tutor, I recall a tutor who used to offer support to students via email, especially when these students were unable to attend the consultation at the writing centre. The administrator would make the booking as an online booking for the purposes of giving feedback via an email. While this limited the conversation and the ability of the tutor to relate to the student, the tutor elected to remain empathetic and sensitive to the student's needs in relation to the assignment, despite the lack of physical interaction. In one email the tutor stated:

Dear [Student's name].

This is feedback to your draft, which you brought to the writing centre on 9 May 2017. Your essay should always meet two general objectives. First, to convey an understanding to the reader, and secondly, to answer the requirements of the task. With regard to the first requirement, the reader, who is your lecturer or reader, should know what you intend to write about. Secondly, you should understand what you are supposed to write about before you actually start writing. These two requirements are summarised as the introduction, main argument(s), and conclusion of your essay. In the introduction, give an overview of your essay and tell the reader what you are going to do. You have done this well in the first paragraph and you are commended for this. In the main argument(s), arrange your paragraphs to give a point and an explanation (for this kind of essay). You indicate in the introduction that you are going to give a detailed position of the main reasons, and an explanation of the emotional and practical reasons that motivated you to study. It is therefore advisable that you use distinct paragraphs to 
reflect this. In addition, the lecturer has indicated that he gave you feedback. Engage that feedback with this essay.

Extract from email (2017)

A closer reading of the email indicates that the tutor's approach was synonymous with Weirick et al.'s (2017) application of the type, focus, and mode of comments. In respect to the type of comment, the first seven lines relate to what the student was expected to do regarding the content of the assignment. The focus comments relating to the organisation of the paper were evident in lines 6-7 of the email. The third aspect, the mode of the comment, was imbued in the corrective and conversational tone of the entire email. I am unaware as to the tutor's knowledge of Weirick et al.'s (2017) principles; this feedback, however, shows that communication in online spaces can be effective, where the tutor is able to balance power and authority to help maintain the identity of the student. This enables the communication of feedback to be effective to this end.

However, even if training were to be offered, it may not necessarily be the only solution. The training for online consultation has to come from the tutor to the student, especially when there is specific software that has to be used (Weirick et al. 2017). This software could be costly, computers have to be maintained, there should be accessibility to the online platform, and both parties should be available for the consultation to be carried out to a logical conclusion (Purdy and DeVoss 2015). Despite the challenges, help in academic writing should be accessible to students whether in a physical or online space. As such, some students, especially of undergraduate programmes, find it difficult to use the software. In addition, the computers may need to be upgraded at regular intervals, workstations need to be available, and venues should be provided with effective security to ward off theft. In the event that smartphone applications are to be developed, funding will inevitably need to be sourced and secured. This calls for further investment in writing centres by universities and the Government.

\subsection{Use of spoken language as written language}

Research by Mackiewicz and Thompson (2018) indicates that a tutor's spoken words greatly affect the subsequent writing of the student. The key issue here is how the tutor places the student in an environment to learn, recognise, and own his or her own work. The extracts that the authors cite show that the tutors identify the problem with words and propose what the replacements should be. It is argued that where the tutor engages his/her power in this manner, the student's identity is stifled (Clarence 2011, Farao 2017). In addition, although the tutor still exhibits confidence that the student may rely on in order to get feedback on the spoken written language, it is on the brink of authoritarianism (Carino 2003). This is exacerbated by the fact that the tutors in this study are either first-language speakers of English or additional-language users of English. This is a contrast to the linguistic challenges that some tutors may experience due to the fact that English is not their first language (Nakatake 2013). In such a position, the ability to aid the student while balancing power, authority, and identity is a challenge, especially when there are physical interactions between the tutor and student. It is argued that, while a tutor should use spoken language to aid the improvement of the student's written language, the balance of power, authority, and identity is important. The online environment that only deals with text can be very useful, as a linguistically challenged tutor who is conversant with the language of the written text may be very resourceful in giving written feedback. 
With particular regard to the UWC Writing Centre, the need to balance power, authority, and identity in the use of spoken written language formed the key challenge due to the fact that English was not the first language of the tutor. I recall that the vibrant linguistic and cultural environment of UWC's campus embraced both the students and the tutors as they were not first-language speakers of English. As a result, the solution to probable upcoming and challenging sessions were punctuated by tutor-to-tutor consultations as a way of obtaining clarity on how the student would be assisted. The physical environment, as such, turned out to be very beneficial to the tutors in preparation for the sessions. This approach can work for online consultations provided that tutors are able to consult each other before online feedback is sent to the student. It suffices to note that the tutor dealing with only text (Breuch 2005) could be more effective when using comments for the student to consider.

\subsection{Questioning}

As regards questioning, and indicated earlier, Munje et al. (2018) interrogate the art of questioning and clarification as effective tools that aid traditional consultation. In terms of power, authority, and identity, the authors argue that questioning enables the student to own his/her writing, to improve it, and eventually to exhibit growth in writing (Munje et al. 2018). Although the downside to literature is the physical positioning of tutors alongside students, the online conundrum is solved by Weirick et al.'s (2017) findings on how to give asynchronous feedback through articulated use of comments. In addition, the lack of insights on the nature of student writers in an online space (Van Waes et al. 2014) can be solved by the kinds of question that the tutor puts to the student (Munje et al. 2018) using Weirick et al.'s (2017) approach to online feedback.

\section{Conclusion}

The onslaught of the \#FeesMustFall protests inhibits a reflection of various challenges that a physical writing centre faces when students cannot access it. As such, the conversation herein points to the need to approach this possible inaccessibility in terms of potential causes other than just student protests. While the emphasis here has been on the tutor, more needs to be done for the student to, firstly, benefit from an online environment, and secondly, benefit from the tutor's help. While the challenges of the actual consultation lie with the tutor, the challenge to put the student in the online space and to make it accessible to him or her are beyond the tutor's mandate.

The evaluation of the writing centre as a physical space, the shift to an online space, and the context of the \#FeesMustFall protests indicated a need for the tutor to balance power and authority, on the one hand, and to maintain the identity of the student, on the other. The methodological aid of Critical Interpretative Synthesis and my personal reflections as a tutor showed that the literature highlighted how the challenges in physical writing centres can be dealt with in online writing centres. While the issue of interdisciplinary training arises, the tutor's ability to aid students in both environments is a fundamental issue. The tutor's ability to balance power and authority extends from the physical interactions to the online space through the nature of the comments $\mathrm{s} /$ he gives the student.

The use of emails during periods of disruption or inaccessibility to physical writing centres offers an interim solution. In the long term, there should be a shift from emails to interactive software where the tutor and student can chat online as with a face-to-face tutorial. Furthermore, 
online resources should be sourced or developed which can then be downloaded and used by the students to improve their writing (Martinez and Olsen 2015) despite disruptions at tertiary institutions. The development of applications on smartphones can also aid students to make use of online writing centres. Ideally, these applications should be able to maintain offline functionality for the student to use when s/he lacks data bundles or access to WiFi.

The lack of conversational functionality should be addressed by the tutor's deliberate decision to be empathetic and to use language and rhetorical questions that offer a platform for the student to engage with the feedback. The point of departure is in the tutor's exercise of care with the word choices s/he makes in order to avoid misinterpretation. I acknowledge that this usually works well when both the tutor and the student speak English as a first language. Although this may not work as adequately when, for example, the tutor speaks English as a first language and the student uses English as an additional language, empathy can still be shown by the tutor in the comments in the text and/or in the rhetorical questions posed to help the student reflect on and address the feedback. Thus, the closure of the physical facilities should be mitigated in the interim by the use of emails. The tone that the tutor uses in person should be evident in the comments s/he sends to the student, which will then balance the issues of power, authority, and identity.

The student protests, and the disruptions to learning that they caused, should be viewed as a call to improve the operation of writing centres. One major operational improvement, I suggest, is to relocate these centres from their physical to online spaces during periods of disruption or when students cannot access the writing centre in person for good reason. At the core of the solution is appropriate training that should be reflected in the demeanour of a tutor and replicated through email. This conversation on transitional space should not be vertically focused on principles to improve the pedagogical goals of the writing centre as a physical space; rather, the conversation should be horizontally aligned to extend these benefits to the online spaces in higher education.

In the long run, the administration of the university should lobby for resources that enable the online operation of writing centres, especially during times of disruption. University administration should also take Government to task in order to be allocated these much-needed resources. Without a doubt, the willingness of the tutors and the students to perform their roles as individuals will ultimately allow them to benefit from these online platforms.

\section{References}

Ako-Arrey, D.E., M.C. Brouwers, J.N. Lavis and M.K. Giacomini. 2015. Health systems guidance appraisal - A critical interpretive synthesis. Implementation Science 11(1): 9-29. https://doi.org/10.1186/s13012-016-0373-y

Archer, A. and R. Richards. 2011. Writing centres as alternate pedagogical spaces. In A. Archer and R. Richards (eds.) Changing spaces: Writing centres and access to higher education. Stellenbosch: African SUN MeDIA. pp. 5-16. 
Arzt, J., K.E. Barnett and J. Scoppetta. 2009. Online tutoring: A symbiotic relationship with writing across the curriculum initiatives. Across the Disciplines: Interdisciplinary Perspectives on Language, Learning, and Academic Writing 6(2): 1-16.

Badat, S. 2016. Deciphering the meanings, and explaining the South African higher education student protests of 2015-16. Pax Academica 1/2: 71-106.

Boehm, D. 2009. The work and art of writing center tutor training. Available online: https://zeitschrift-schreiben.eu/globalassets/zeitschrift-

schreiben.eu/2009/boehm_tutor_training.pdf(Accessed 19 September 2019).

Bonell, C., J. Farah, A. Harden, H. Wells, W. Parry, A. Fletcher, M. Petticrew, J. Thomas, M. Whitehead, R. Campbell, S. Murphy and L. Moore. 2013. Systematic review of the effects of schools and school environment interventions on health: Evidence mapping and synthesis. Public Health Research 1(1): 1-8. https://doi.org/10.3310/phr01010

Boughey, C., and S. McKenna. 2016. Academic literacy and the decontextualised learner. Critical Studies in Teaching and Learning 4(2): 1-9.

Breuch, L.A.K. 2005. The idea(s) of an online writing center: Searching for a conceptual model. The Writing Center Journal 25(2): 21-38.

Breuch, L.A.K. and S.J. Racine. 2000. Developing sound tutor training for online writing centers: Creating productive peer reviewers. Computers and Composition 17(3): 245-263. https://doi.org/10.1016/s8755-4615(00)00034-7

Burch, P., A. Good and C. Heinrich. 2016. Improving access to, quality, and the effectiveness of digital tutoring in K-12 education. Educational Evaluation and Policy Analysis 38(1): 65-87. https://doi.org/10.3102/0162373715592706

Carino, P. 2003. Power and authority in peer tutoring. In M.A. Pemberton and J. Kinkead (eds.) The center will hold: Critical perspectives on writing center scholarship. Logan: Utah State University Press. pp. 96-113. https://doi.org/10.2307/j.ctt46nxnq.9

Clarence, S. 2011. Writing in the academy: Collaborative writing development with students and lecturers at the UWC writing centre. In A. Archer and R. Richards. (eds.) Changing spaces: Writing centres and access to higher education. Stellenbosch: African SUN MeDIA. pp. 101-114.

Da Costa, B.R. and P. Jüni. 2014. Systematic reviews and meta-analyses of randomized trials: Principles and pitfalls. European Heart Journal 35(47): 3336-3345. https://doi.org/10.1093/ eurheartj/ehu424

Deane, M. and L. Ganobcsik-Williams. 2012. Providing a hub for writing development. In C. Thaiss, G. Bräuer, P. Carlino, L. Ganobcsik-Williams and A. Sinha (eds.) Writing programs worldwide: Profiles of academic writing in many places. Fort Collins: Parlor Press/The WAC Clearinghouse. pp. 189-202. 
Delpit, L. 1995. Teachers, culture, and power: An interview with Lisa Delpit. In D.P. Levine, R. Lowe, B. Peterson and R. Tenorio (eds.) Rethinking schools: An agenda for change. New York: The New Press. pp. 136-147.

Denny, H. 2005. Queering the writing center. The Writing Center Journal 25(2): 39-62.

Dixon-Woods, M., D. Cavers, S. Agarwal, E. Annandale, A. Arthur, J. Harvey, R. Hsu, S. Katbamna, R. Olsen, L. Smith, R. Riley and A.J. Sutton. 2017. Conducting a critical interpretive synthesis of the literature on access to healthcare by vulnerable groups. BMC Medical Research Methodology 6(35): 35-48. https://doi.org/10.1186/1471-2288-6-35

Eakin, J.M. and E. Mykhalovskiy. 2003. Reframing the evaluation of qualitative health research: Reflections on a review of appraisal guidelines in the health sciences. Journal of Evaluation in Clinical Practice 9(2): 187-194. https://doi.org/10.1046/j.1365-2753.2003. $\underline{00392 . x}$

Faroa, B.D. 2017. Considering the role of tutoring in student engagement: Reflections from a South African university. Journal of Student Affairs in Africa 5(2): 1-15. https://doi.org/10. 24085/jsaa.v5i2.2699

Greenhalgh, T., G. Robert, F. Macfarlane, P. Bate, O. Kyriakidou and R. Peacock. 2005. Storylines of research in diffusion of innovation: A meta-narrative approach to systematic review. Social Science \& Medicine 61(2): 417-430. https://doi.org/10.1016/j.socscimed.2004. $\underline{12.001}$

Grimm, N.M. 1999. Good intentions: Writing center work for postmodern times. Portsmouth: Boynton/Cook.

Hoon, T.B. 2009. Assessing the efficacy of writing centres: A review of selected evaluation studies. Pertanika Journal of Social Sciences and Humanities 17(2): 47-54.

Langa, M. (ed.) 2017. \#Hashtag: An analysis of the \#FeesMustFall movement at South African universities. Johannesburg and Cape Town: Centre for the Study of Violence and Reconciliation.

Mackiewicz, J. and I. Thompson. 2018. Spoken written-language in writing center talk. Linguistics and Education 47: 47-58. https://doi.org/10.1016/j.linged.2018.07.003

Martinez, D. and L. Olsen. 2015. Online writing labs. In B.L. Hewett and K.E. DePew (eds.) Foundational practices of online writing instruction. Fort Collins: The WAC Clearinghouse. pp. 183-210.

McFerran, K.S., C. Hense, L. Medcalf, M. Murphy and R. Fairchild. 2017. Integrating emotions into the critical interpretive synthesis. Qualitative Health Research 27(1): 13-23. https://doi. org/10.1177/1049732316639284

Mitoumba-Tindy, H. 2017. Working in the interspace between subject knowledge and academic literacies: Writing centres as a zone of proximal development. In S. Clarence and L. 
Dison (eds.) Writing centres in higher education: Working in and across the disciplines. Stellenbosch: African SUN MeDIA. pp. 67-80.

Monroe, B. 1998. The look and feel of the OWL conference. In E. Hobson (ed.) Wiring the writing center. Logan: Utah State University Press. pp. 3-24. https://doi.org/10.2307/j.ctt $\underline{46 \mathrm{nzf} 8.5}$

Munje, P.N., R.D. Nanima and S. Clarence. 2018. The role of questioning in writing tutorials: A critical approach to student-centred learning in peer tutorials in higher education. Mentoring \& Tutoring: Partnership in Learning 26(3): 336-353. https://doi.org/10.1080/13611267.2018. $\underline{1511953}$

Nakatake, M. 2013. Challenges and possibilities in tutorials in a writing center in Japan. The Language Teacher 37(6): 17-20.

Nichols, P. 2017. 'Hopeful' directions for writing centres in South Africa: From safe spaces to transitional sites of articulating practice. Stellenbosch Papers in Linguistics Plus 53(1): 182-194. https://doi.org/10.5842/53-0-741

Nyamnjoh, F.B. 2016. \#RhodesMustFall: Nibbling at resilient colonialism in South Africa. Bamenda: Langaa Research and Publishing Common Initiative Group. https://doi.org/10.2307/ j.ctvmd $84 \mathrm{n} 8$

Peck, R. 2017. CBC radio interview: Raoul Peck brings James Baldwin's powerful gaze to the big screen. Available online: http://www.cbc.ca/radio/q/friday-feb-24-2017-raoul-peckreginald-edmundand-more-1.3995507/raoul-peck-brings-james-baldwin-s-powerful-gaze-tothe-big-screen-1.3995526 (Accessed 30 September 2019).

Pillay, S.R. 2016. Silence is violence: (Critical) psychology in an era of Rhodes Must Fall and Fees Must Fall. South African Journal of Psychology 46(2): 155-159. https://doi.org/10.1177/ $\underline{0081246316636766}$

Pound, P., N. Britten, M. Morgan, L. Yardley, C. Pope, G. Daker-White and R. Campbell. 2005. Resisting medicines: A synthesis of qualitative studies of medicine taking. Social Science and Medicine 61(1): 133-155. https://doi.org/10.1016/j.socscimed.2004.11.063

Pozzebon, M. 2004. Information systems research. Boston: Springer.

Purdy, J.P. and D.N. DeVoss. 2015. Making space to theorize and situate space making: An introduction. In J.P. Purdy and D.N. DeVoss (eds.) Making space: Writing instruction, infrastructure, and multiliteracies. Ann Arbor: University of Michigan Press. Available online https:/quod.lib.umich.edu/cgi/t/text/idx/d/drc/mpub7820727/1:2/--making-space-writinginstruction-infrastructure?g=dculture;rgn=div1;view=fulltext;xc=1 (Accessed 19 September 2019). https://doi.org/10.3998/mpub.7820727

Shabanza, K.J. 2017. Enhancing reflection on writing: Using group writing consultations to develop meta-awareness of disciplinary writing. In S. Clarence and L. Dison (eds.) Writing 
centres in higher education: Working in and across the disciplines. Stellenbosch: African SUN MeDIA. pp. 161-174.

Tan, B.H. 2011. Innovating writing centers and online writing labs outside North America. Asian EFL Journal 13(2): 390-417.

Tetui, M., J.M. Zulu, A.-K. Hurtig, E. Ekirapa-Kiracho, S.N. Kiwanuka and A.-B. Coe. 2018. Elements for harnessing participatory action research to strengthen health managers' capacity: A critical interpretive synthesis. Health Research Policy and Systems 16(33): 1-14. https://doi.org/10.1186/s12961-018-0306-0

Thompson, I. 2009. Scaffolding in the writing center: A microanalysis of an experienced tutor's verbal and nonverbal tutoring strategies. Written Communication 26(4): 417-453. https://doi. org/10.1177/0741088309342364

Van Waes, L., D. van Weijen and M. Leijten. 2014. Learning to write in an online writing center: The effect of learning styles on the writing process. Computers \& Education 73: 60-71. https://doi.org/10.1016/j.compedu.2013.12.009

Weirick, J., T. Davis and D. Lawson. 2017. Writer L1/L2 status and asynchronous online writing center feedback: Consultant response patterns. Learning Assistance Review 22(2): 9-38.

Weissbach, R.S. and R.C. Pflueger. 2018. Collaborating with writing centers on interdisciplinary peer tutor training to improve writing support for engineering students. IEEE Transactions on Professional Communication 61(2): 206-220. https://doi.org/10.1109/tpc. $\underline{2017.2778949}$

Zakharov, W. and C. Maybee. 2019. Bridging the gap: Information literacy and learning in online undergraduate courses. Journal of Library \& Information Services in Distance Learning 13(1-2): 215-225. https://doi.org/10.1080/1533290x.2018.1499256 